\title{
反転ねじり型エネルギ一吸収構造とその安価な部分加熱ねじり加工法
}

\author{
梁 狄 ${ }^{* 1}$ ，楊 陽*2，孔 呈海*3，景 陽 ${ }^{* 4}$ ，趙 巍 ${ }^{* 5}$ ，趙 希禄*6，萩原 一郎*7
}

\section{Reversed torsion type crash energy absorption structure and its inexpensive partially heated torsion manufacturing method}

\author{
Di LIANG $^{* 1}$, Yang YANG ${ }^{* 2}$, Chenghai $\mathrm{KONG}^{* 3}$, Yang JING ${ }^{* 4}$, Wei ZHAO ${ }^{* 5}$, Xilu ZHAO*6 \\ and Ichiro HAGIWARA ${ }^{* 7}$ \\ ${ }^{* 1,{ }^{6}}$ College of Mechanical Engineering, Saitama Institute of Technology \\ 1690 Fusaiji, Fukaya-shi, Saitama 369-0293, Japan \\ ${ }^{* 2,{ }^{* 7}}$ Institute for Advanced Study of Mathematical Sciences, Meiji University \\ 4-21-1 Nakano, Nakano-ku, Tokyo 164-8525, Japan \\ ${ }^{* 3}$ Steel Division of Topy Industries Co., Ltd. \\ 1 Akemi-cho, Toyohashi-shi, Aichi 441-8510, Japan \\ ${ }^{*}$ Tsubakimoto Chain Co. \\ 20 Shinko, Hanno-shi, Saitama 357-8510, Japan \\ ${ }^{* 5}$ Weichai Global Axis Technology Co., Ltd. \\ 1-1-1 Minami-Aoyama, Minato-ku, Tokyo 107-0062, Japan
}

Received: 24 November 2020; Revised: 24 January 2021; Accepted: 15 February 2021

\begin{abstract}
In order to develop a new crash energy absorb structure, in this paper, we propose a new reverse torsion type origami structure (RTO) and a partial heating torsion method. The RTO can adjust the distribution of crash buckling wrinkles by arranging polygonal lines along the side surface, and can have the property of stably continuing accordion-type crushing deformation during the crushing process. In the newly proposed partial heating torsion method, the square pipe material is divided into multiple stages along the axial direction, and a formed RTO can be obtained by repeating partial heating and simple torsion forming for each stage. In addition, by applying the method of heating only to the torsional deformed part, it is possible to process with a small processing load, and it is possible to realize the simplification of the jig for fixing the square tube material. This study examines the problems of forming RTO by the partial heating and torsion method and the forming shape quality. We will also examine whether the obtained RTO has sufficient crash energy absorption performance.
\end{abstract}

Keywords: Reversed torsion origami structure, Energy absorbing, Torsion forming method, Crash model, Origami engineering

\section{1. 緒 言}

衝突エネルギー吸収体として設計される工業製品はよく見受けられる．自動車の前面衝突用のエネルギー吸収 部材として，エンジンを左右から挟むようにして前後方向にボディ先端まで設置されているサイドメンバーとい う中空の細長い角柱構造は，前面衝突時に横へ折れ曲がるオイラー座屈が生じやすく，一旦それが発生すると， サイドメンバーは折れ曲がり，衝突エネルギー吸収量は極端に下がる，それに起因して，圧潰変形途中で，この

\footnotetext{
No.20-00425 [DOI:10.1299/transjsme.20-00425], J-STAGE Advance Publication date : 25 February, 2021

${ }^{* 1}$ 埼玉工業大学 大学院工学研究科システム工学専攻（下369-0293 埼玉県深谷市普済寺 1690)

*2 明治大学 先端数理科学インスティテュート（テ164-8525 東京都中野区中野 4-21-1）

*3 トピー工業（株）（广441-8510 愛知県豊橋市明海町 1)

*4 (株) 椿本チエイン（厂357-8510 埼玉県飯野市新光 20）

*5 濰柴鴻基科技（株）（广107-0062 東京都港区南青山 1-1-1）

*6 正員, 埼玉工業大学 大学院工学研究科システム工学専攻

${ }^{* 7}$ 正員, 名誉員, フェロー, 明治大学 先端数理科学インスティテュート

E-mail of corresponding author: ihagi@meiji.ac.jp
} 
ようなオイラー座屈が生じることはなく，できるだけ圧潰変形を長く続け，衝突エネルギー吸収量を最大にする ことは車両部品の衝突設計において最も重要な課題である.

そのため，萩原らはサイドメンバーの圧縮座屈の波長を求め，座屈の腹部と節部に切欠きまたは突起を入れる ことによって横へ折れ曲がる問題を解決し, 確実にアコーディオン状の圧潰変形の実現を得た (萩原他, 1991, 北 川他, 1991, Hagiwara et al., 1991, Kitagawa et al., 1992）。しかし，自らのかさばりが邪魔となり自長の 70\%程度の圧 潰変形量しか得られず, また, 圧潰反力の初期ピーク荷重が高すぎるという久点も解決できていない. そこで, 萩原らは折り畳める折紙構造に関する研究成果を活かし, 側面壁に折線を入れる反転らせん型折紙構造 (Reversed Spiral Origami Structure；RSO）を適用することによって，圧潰変形量が常に自長の 90\%以上となる特性を得，初 期ピーク荷重も和らげる結果を得ている（萩原，灘，2003, 萩原他，2004）。このような優れた衝突エネルギー吸 収性能を示すものの, 圧潰変形に対する抵抗反力は低くなり, 同重量で現行構造と比較して $70 \%$ 程度の衝突エネ ルギー吸収量しか得られなかった。 これを改善するため, Wu らはサブディビジョン法を RSO 設計に適用し検討 を行ったが（Wu et al., 2007），現行構造に勝る衝突エネルギー吸収量の高い構造を得ることができなかった，そ こで, 趙らはRSO のパラメトリック設計の表現法を考案し，RSO に関する最適化解析を適用した結果，同重量 で現行構造と比較し，衝突エネルギーが約 1.4～1.7 倍多く吸収できることを示した（趙他，2010）.

しかし, 得られた RSO は 3 次元的に複雑な形状をもつため, 容易に加工できず, 現時点では, 高価なハイドロ フォーミング法に拠らざるを得ない，孔らはハイドロフォーミング成形後の RSO の肉厚ができるだけ均一にな ることを目的とし，成形パラメータの組合せを求める最適化解析を行い，八イドロフォーミング法を用い RSO が 加工できることを確認したが（孔他，2014，Kong et al.,2017）, 加工に必要な設備と金型は複雑であり, 生産コス トは高く, さらに張り出し成形モードが含まれるため, 局所的に肉厚が大幅に薄くなる欠陥が見受けられ，こう したハイドロフォーミング法の問題に起因して，RSO の実用化は大きく遅れているのが現状である.

本報では，RSO に代わり新たに反転㸚じり型折紙構造（Reversed Torsion Origami Structure; RTO）を提案する. RTO を容易に加工寸るために新しく提案する部分加熱衩じり加工法は, 角パイプ素材を軸方向に沿って段に分け て，段毎に単純な据じり成形を繰り返すだけで成形品を得ることができる．また，ねじり塑性変形部分だけに対 し加熱する方法を適用することによって，小さな加工荷重で加工できると同時に角パイプ素材を固定する治具の 簡素化も実現できる. 部分加熱ねじり加工法の主な利点としては, 従来の加工法で利用される高圧の油圧システ ムなど複雑な加工設備は不要で, 部分的に単純な㧖じり成形だけで済むので加工コストの大幅な節減が得られ, さらに内部の高い液圧による張り出し変形しないため局所的に肉厚が大幅に薄くなる問題も回避できると期待さ れる. 本報は RTO を部分加熱衴じり加工法で成形する問題点や成形品質等と共に, 部分加熱ねじり加工法で得 られる RTO が十分な衝突エネルギー吸収性能を持つかについて検討を行い，実用化に向けた知見をまとめる.

\section{2. 反転ねじり型折紙構造（RTO）の提案}

図 1(a)に示寸自動車のエネルギー吸収材であるサンドメンバーは中空で細長い形状を持つため，圧潰変形過程 において，横へ折り曲がりやすく，折れ曲がると衝突エネルギー吸収性能が極端に落ちる．その理想的な衝突変 形パターンとして, 同図(b)に示寸ように出来るだけ初期ピーク荷重值が低く, 安定な軸方向の圧潰変形が長く続 くことが求められている. 同図 ( b ) の理想的な衝突圧潰変形パターンを実現することを目指し, 本報は図 2 に示

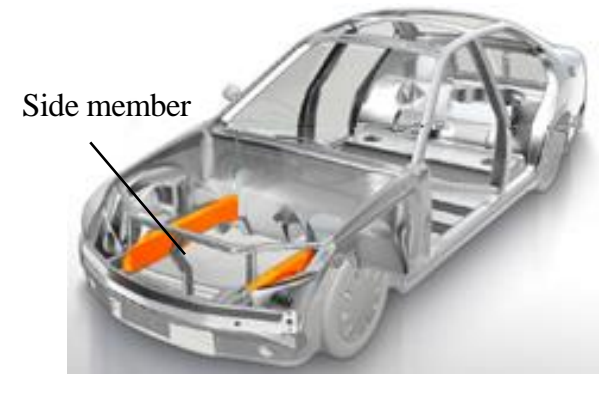

(a)

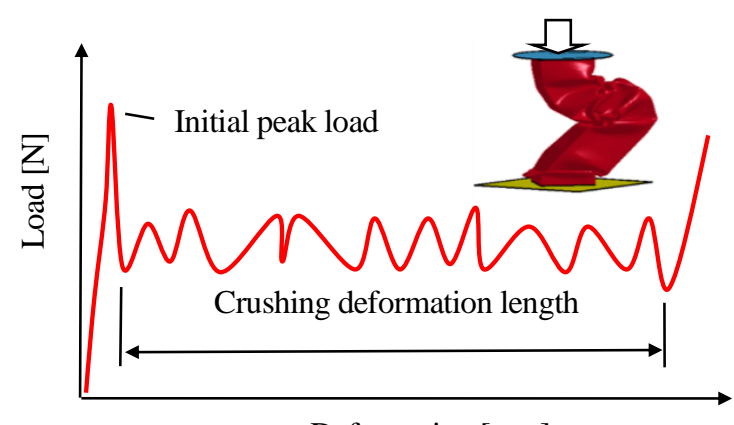

(b)

Deformation $[\mathrm{mm}]$

Fig.1 (a) The vehicle side member. (b) The diagram of crash load and crushing deformation. 


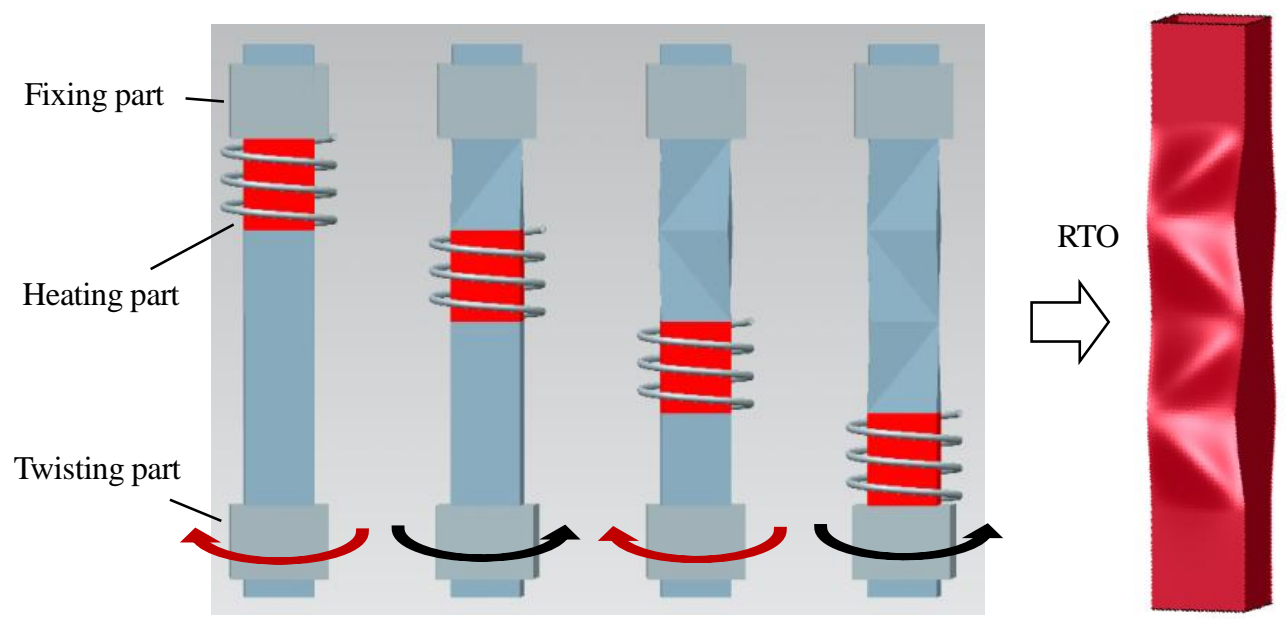

Fig.2 The reverse twist type origami structure (RTO) and partial heating rotation processing method. the three steps in the torsion forming process: (1) fix the first segment and twist the segment through a certain angle, thus deforming the second segment; (2) move the jig one segment along the axial direction; (3) repeat step (1), twisting in the opposite direction.

す RTO とその簡易的な加工方法を提案する. 図 2 では, 正方形断面の角パイプに対し軸方向に沿って段に分け る. 角パイプの両端に固定治具を設け, 片方の端部を完全固定にして，もう一つの端部を回転できるようにする. 図 2 の左から右へ示すように，一段の長さに対応する部分だけに高周波誘導（Induction Heating; IH）加熱してか ら, 回転端を回転させる. 角パイプ素材の加熱部分に対するねじり塑性成形の抵抗力が比較的小さくなることを 利用して，その加熱される部分だけをねじり塑性変形させる. その後, 冷却してから, IH 加熱コイルを一段分ず らして, 各段を順番に部分加熱ねじり変形させる. その結果, 図 2 の右端に示すような RTO 構造が得られる.

\section{3. 部分加熱ねじり加工法の成形性能に関する検討}

図 2 に示す部分加熱ねじり加工法を実施する前に, FEM を利用して部分加熱衩じり成形過程のシミュレーショ ンを行い，固定治具と角パイプ素材の間に生じる相対変位やねじり塑性変形部分の角パイプ素材に与える加熱温 度の影響などを検討する.

ここでは，汎用ソフトウェア LS-DYNA を使いRTO の部分加熱ねじり成形過程を解析寸る. 図 3 に RTO の成 形解析モデルを示す. 節点数は 15101, 四角形アイソパラメトリックシェル要素を使用し要素数は 15000 , 角パイ プ素材の要素の平均寸法は $1.0 \mathrm{~mm}$ であり, 毎回の部分加熱衿じり変形の長さは断面辺長と同じ $50 \mathrm{~mm}$ である.

強制ねじり変形角度一時間線図を図 4 に示寸. 角パイプ素材の塑性変形させる部分を加熱した状態で，角パイ プ素材の一端を固定治具で締め付け，他端の固定治具を使い角パイプを回転させて，角パイプに部分ねじり塑性 変形を与える.

後述の試作実験を考慮して，使用寸る角パイプ素材の長さ $300 \mathrm{~mm} ，$ 板厚 $1.6 \mathrm{~mm} ，$ 辺長は上述のように $50 \mathrm{~mm}$ と する. 成形解析に使う材料は軟鋼材とし, 降伏後の硬化特性を図 5 に示寸応力と塑性ひずみ関係で与える. また, 式(1)に示す Cowper-Symonds の式を用い，材料のひずみ速度依存性を考慮する.

$$
\sigma_{y}=\sigma_{y 0}\left[1+\left\{\frac{\dot{\varepsilon}}{c}\right\}\right]^{\frac{1}{p}}
$$

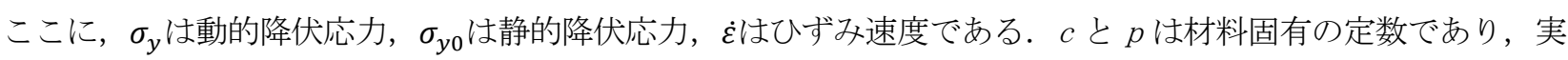
際の自動車衝突解析事例の值を参考に $c=8000$ と $p=8$ とする. 

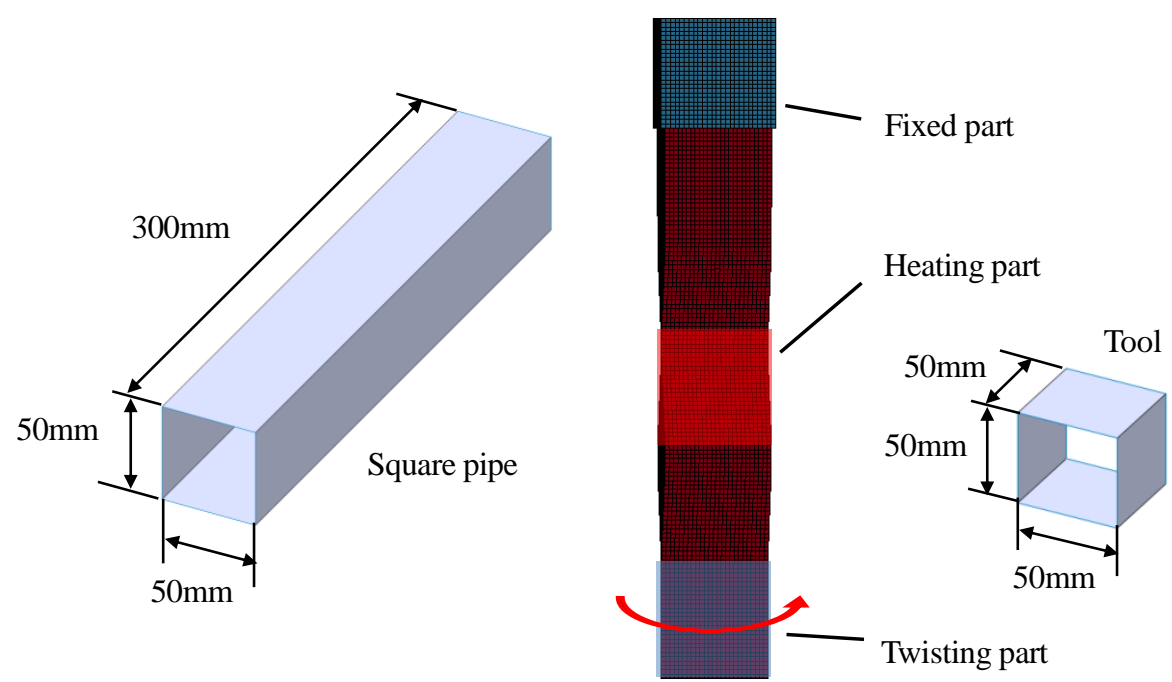

Fig.3 FEM model of RTO. The length is $300 \mathrm{~mm}$, the edge length is $50 \mathrm{~mm}$, and the plate thickness is $1.6 \mathrm{~mm}$.

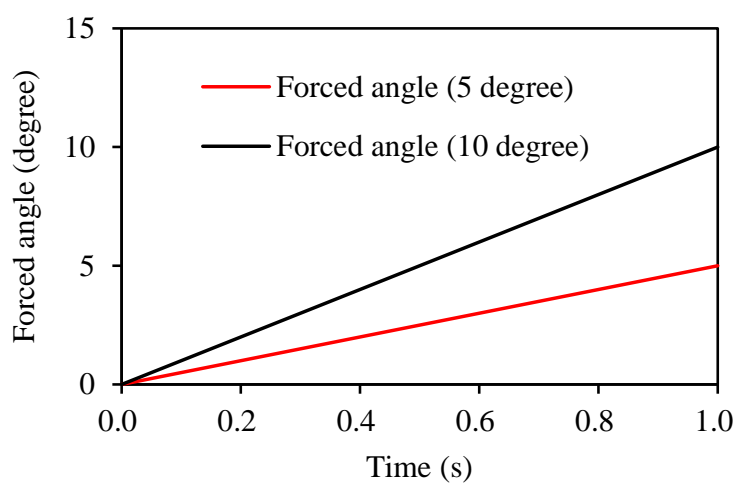

Fig.4 The time series forming load graph.

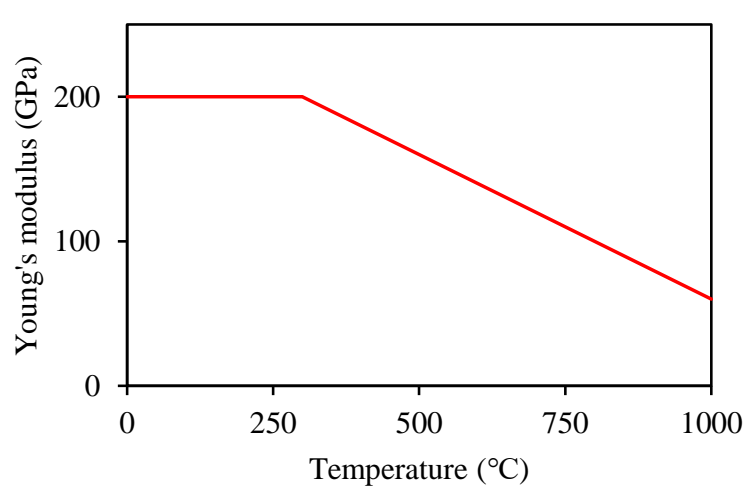

Fig.6 The graph of temperature and young's modulus.

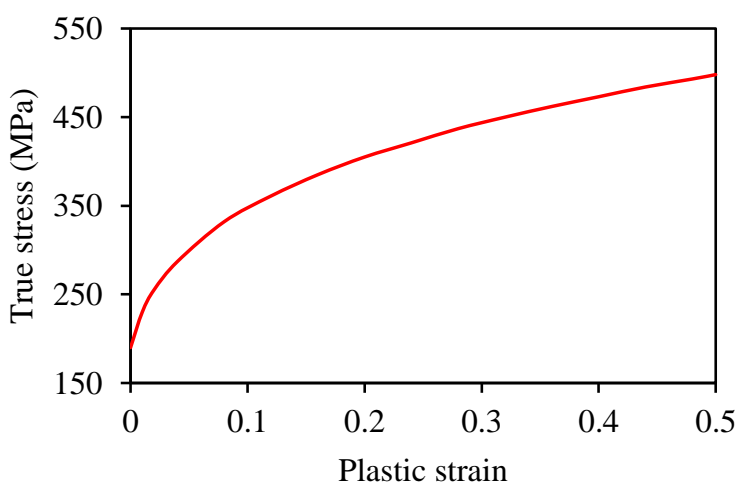

Fig.5 The graph of stress and plastic strain.

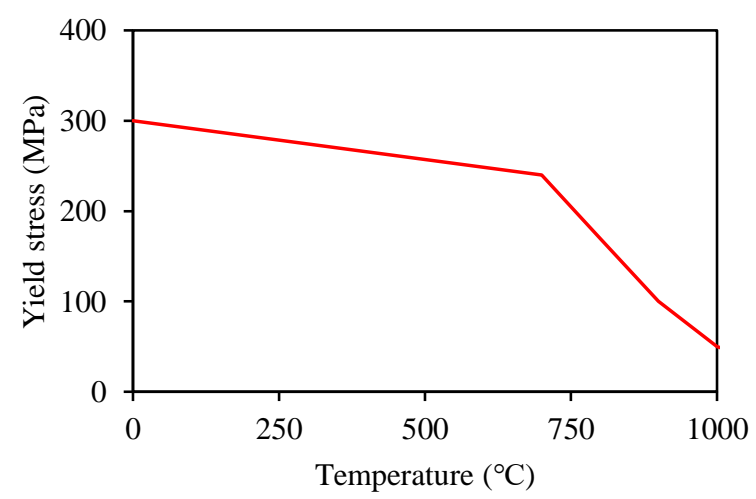

Fig.7 The graph of temperature and yield stress.

加熱による温度の変化に伴う材料のヤング率と降伏応力の温度依存関係については, 図 6 と図 7 に示寸軟鋼 材のデータを用いる．同図から，室温でのヤング率と降伏応力はそれぞれ $200 \mathrm{GPa}$ と $300 \mathrm{MPa}$ とする．なおポア ソン比を 0.3 とする. 成形パイプに対する $\mathrm{IH}$ 部分加熱の温度については, 軟鋼材の熱間塑性加工特性（楠見他， 2012）, 部分加熱衩じり予備試作結果および実際に使用する IH 加熱器の最大加熱温度を参考にして, 本研究にお ける部分加熱温度を $950^{\circ} \mathrm{C}$ とた. 害際に本報の提案する部分ねじり加工法に適用する時, 式(2)に従い高周波誘 導加熱のコイルの電気抵抗や渦電流などを決めることができる. 


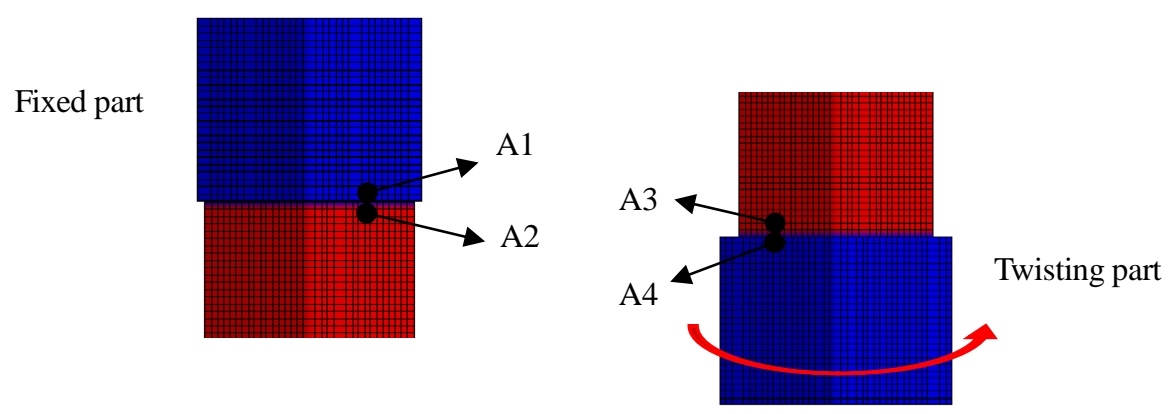

Fig.8 Observation point of relative displacements between fixing jig and formed RTO.

Table 1 Relative displacement between fixing jig and formed RTO (heating temperature $950{ }^{\circ} \mathrm{C}$ ).

\begin{tabular}{|c|c|c|}
\hline \hline & Fixed part (A1-A2) & Twisting part (A3-A4) \\
\hline Relative displacement & $0.002 \mathrm{~mm}$ & $0.006 \mathrm{~mm}$ \\
\hline
\end{tabular}

$$
T=\frac{I^{2} R t}{m C}
$$

ここに, $T$ は温度， $R$ はコイルの電気抵抗， $I$ は流れる渦電流， $m$ は加熱する角筒部分の質量， $C$ は比熱， $t$ は加熱時間である.

部分加熱ねじり加工法の成形過程において，角パイプの内部では固定治具を設けることはなく，外部からの固 定治具だけで角パイプ素材を掴むため，固定治具と角パイプ素材の間で滑り現象を調べる必要がある．図 8 に示 すように固定治具と角パイプ素材の接触する部分から相対変位の観測点を選んで，成形前後の観測点の間にある 相対変位を求め, その結果を表 1 によとめた. 表 1 より，固定治具と角パイプ素材の間にある相対変形は非常に 小さく，部分加熱ねじり加工法では，外部からの固定治具だけで角パイプ素材をねじり塑性加工の要求に満たす ように掴めることが確認できた.

部分加熱ねじり成形法では，固定端と回転端の間に固定される角パイプ素材には均一的なトルク荷重を与えて いる. 部分加熱温度の増加により, ねじり塑性変形に必要な回転トルク荷重が小さくなることが容易に判るが, その関係を定量的に把握し，成形過程において確かに加熱される部分だけをねじり塑性変形させることを確認す る必要がある。

ねじり塑性変形に必要な回転トルク荷重と部分加熱温度の依存関係を確認するため, 図 9(a)に示すように 1 回 のねじり塑性成形の長さだけを取り出しモデル化して，その両側にそれぞれ固定端と回転端の境界条件を設定す る. その中央にある成形部分に対しては，加熱なしの室温の $25^{\circ} \mathrm{C}$ と部分加熱された $950^{\circ} \mathrm{C}$ のつの成形ケースに 分けてそれぞれ成形解析を行う。

加熱なしの場合，角パイプ素材の内部に固定治具を設置しない条件でねじり成形解析したが，外側の固定治具 と角パイプ素材の間の相対滑り変位が大きく, ねじり成形加工は不能となったため, ねじり成形に必要な回転卜 ルクを解析することを目的とする前提で, 固定治具と角パイプ素材の間にある接触条件を剛的結合として成形解 析を行った.

成形解析の結果を図 9(b)に示す. 部分ねじり塑性加工が開始してから, トルクが 0 から急に増加して, その後, 多少トルクの值が変動する傾向が見えるが, 双方のトルクの平均值を比較すると, 室温で部分ねじり塑性加工に 必要となる平均トルク值 $1162.54 \mathrm{Nm}$ に対し, 加熱 $950^{\circ} \mathrm{C}$ でのルク值は $346.83 \mathrm{Nm}$ であり, 部分加熱をすること によって, 加工に必要なトルクは約 3.35 倍小さくなることが判る. この比較結果よって, 角パイプの両端を固定 して, 角パイプの両端の間にある局部的に加熱した条件で, 加熱した部分だけにねじり塑性変形が集中されるこ とが十分に可能と考えられる. 両端を固定治具で掴み, 部分加熱衿じり成形を行う場合, 両端の固定位置は変化 させず, 加熱される成形部分の長さと加熱しない部分の長さは一定として, 一段ずつねじり成形して行く時に必 

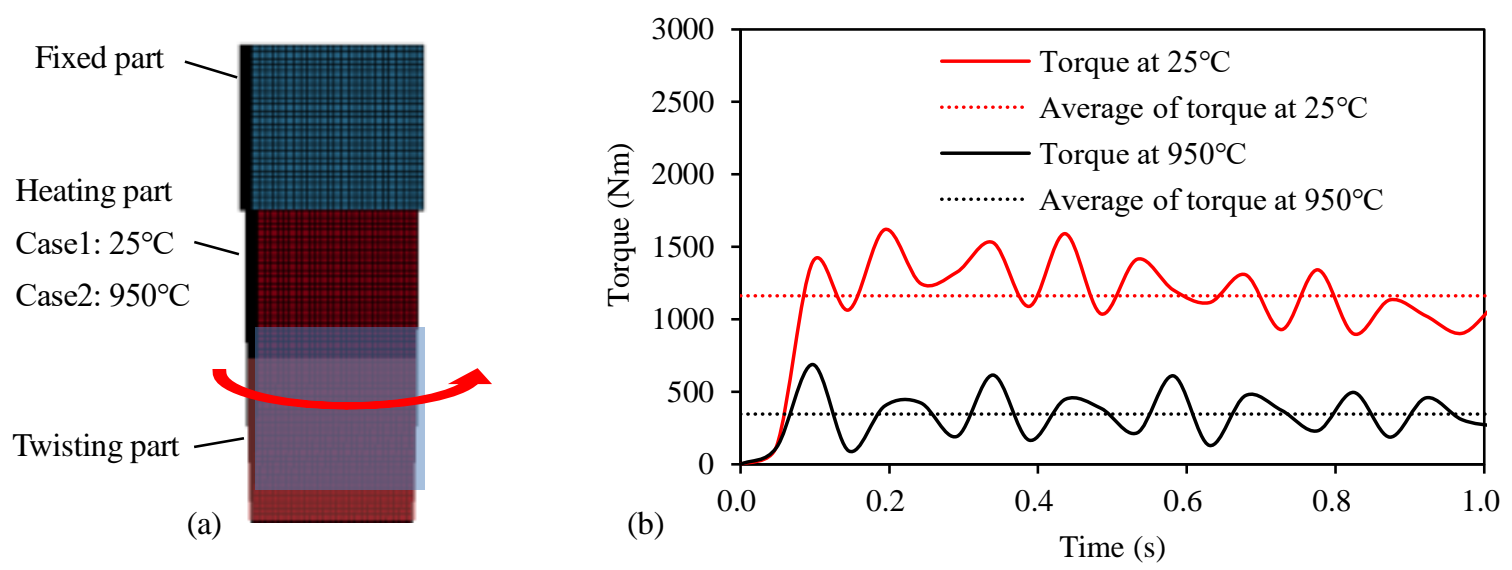

Fig.9 Effect of partial heating temperature on forming resistance. (a) Partial heating forming analysis model. (b) Relationship between heating temperature and torque for torsional plastic forming. The average torque value at $25^{\circ} \mathrm{C}$ is $346.83 \mathrm{Nm}$. The average torque value at $950^{\circ} \mathrm{C}$ is $1162.54 \mathrm{Nm}$.

要なねじり荷重は，加熱された部分の塑性変形荷重に依存するため一定と考えても良い．このように，部分加熱 により加工トルクが小さくなることによって，二つの有利な点がある。一つは，必要な捩り塑性加工トルクが小 さいことから，角パイプ内部の固定治具は無くて良い，もう一つは，加熱された部分が局所的に塑性変形に対す る抵抗力が 3 割以下となるため, 他の部分は塑性変形せず, ねじり塑性変形部分だけがより安定的に加工できる ことになる．斌じり角度は 5 度で部分加熱衩じり成形解析を行い得られた解析結果を図 10 に示す．赤い点線で 囲まれた部分は各成形ステップでの成形部分であり，同図右端のコンター図は成形した RTO の板厚分布を示す. 赤い部分は板厚が厚く，青い部分は板厚が薄いことを示す．最大板厚は(1)部の $1.602 \mathrm{~mm}$ で最小板厚は(2)部の $1.597 \mathrm{~mm}$ である. 初期板厚は $1.6 \mathrm{~mm}$ であることから, 部分加熱ねじり成形法による成形品の板厚変化は $0.19 \%$ 以 内であり，板厚の分布は非常に均一であることを示しており，これは角パイプの塑性変形は単純なねじり成形パ ターンのみであり, 内部から張り出し成形パターンはない原因があると考えられる.
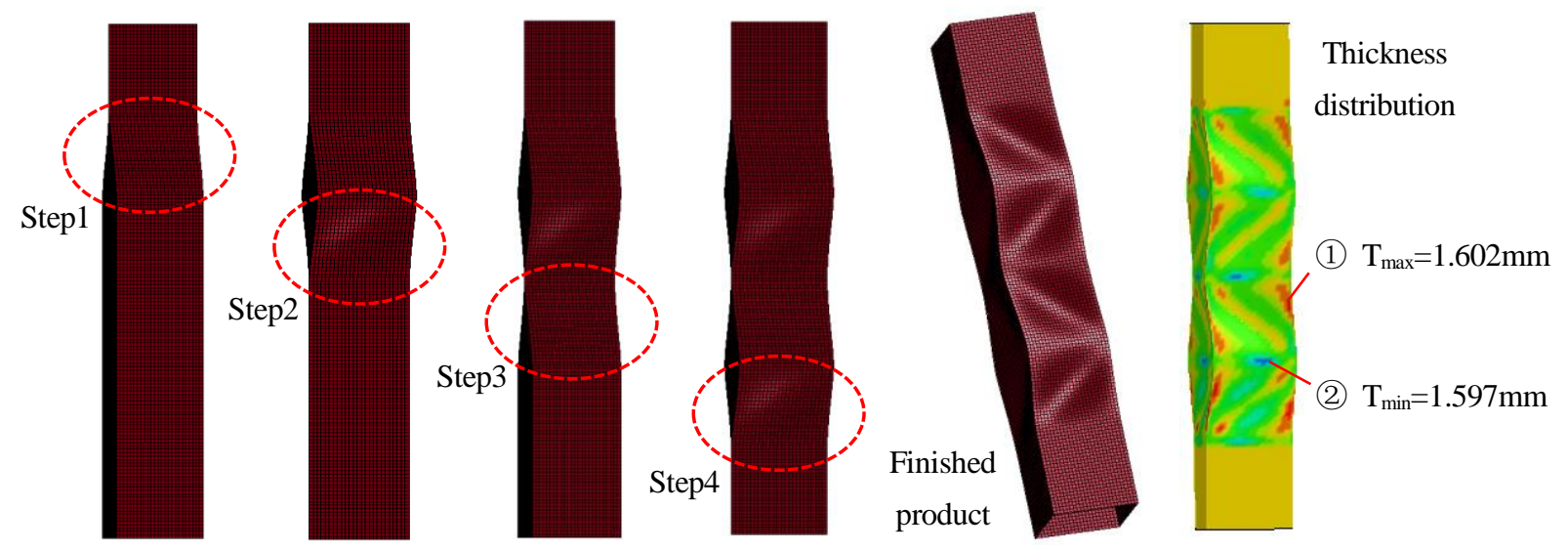

Fig.10 The analysis results of partial heat forming of RTO. The red dotted line shows the forming part of each step. The contour diagram shows the wall thickness distribution, with the thickest value being $1.602 \mathrm{~mm}$ and the thinnest value being $1.597 \mathrm{~mm}$. The initial thickness is $1.6 \mathrm{~mm}$.

確認のため, 水じり角度 10 度で成形する RTO に対して同様な部分加熱成形解析を行う，その結果，最大板厚 は $1.606 \mathrm{~mm}$, 最小板厚は $1.588 \mathrm{~mm}$ となり, 元の板厚 $1.6 \mathrm{~mm}$ より全て $0.375 \%$ 以内の板厚変化を示している. よっ て，部分加熱衴じり加工法の成形過程において安定的に塑性成形できることが示されている．よって，亀裂が発 生する欠陥を回避することに有利であり，試作実験前の成形性能確認ができた. 


\section{4. 試作実験による検証}

提案する RTO の部分加熱ねじり加工性能を検証するため，実際に図 11 に示すような部分加熱䄧り゙り加工の実 験装置を開発した. 図中に示すように, 実験装置は主に加工装置本体, 成形用角パイプの固定治具と IH 加熱器の 3 つの部分から構成される.

加工装置本体のメインフレームの上に 1 対の回転ロールがあり, 回転ロールの中央に成形角パイプの固定治具 を設置する. 成形角パイプは回転ロールの中央に固定される. IH 加熱器はコントローラー, 加熱器本体と加熱コ イルから構成される. 加熱器本体は水平レールの上に設置して, 角パイプを加熱コイルの中央に通す.

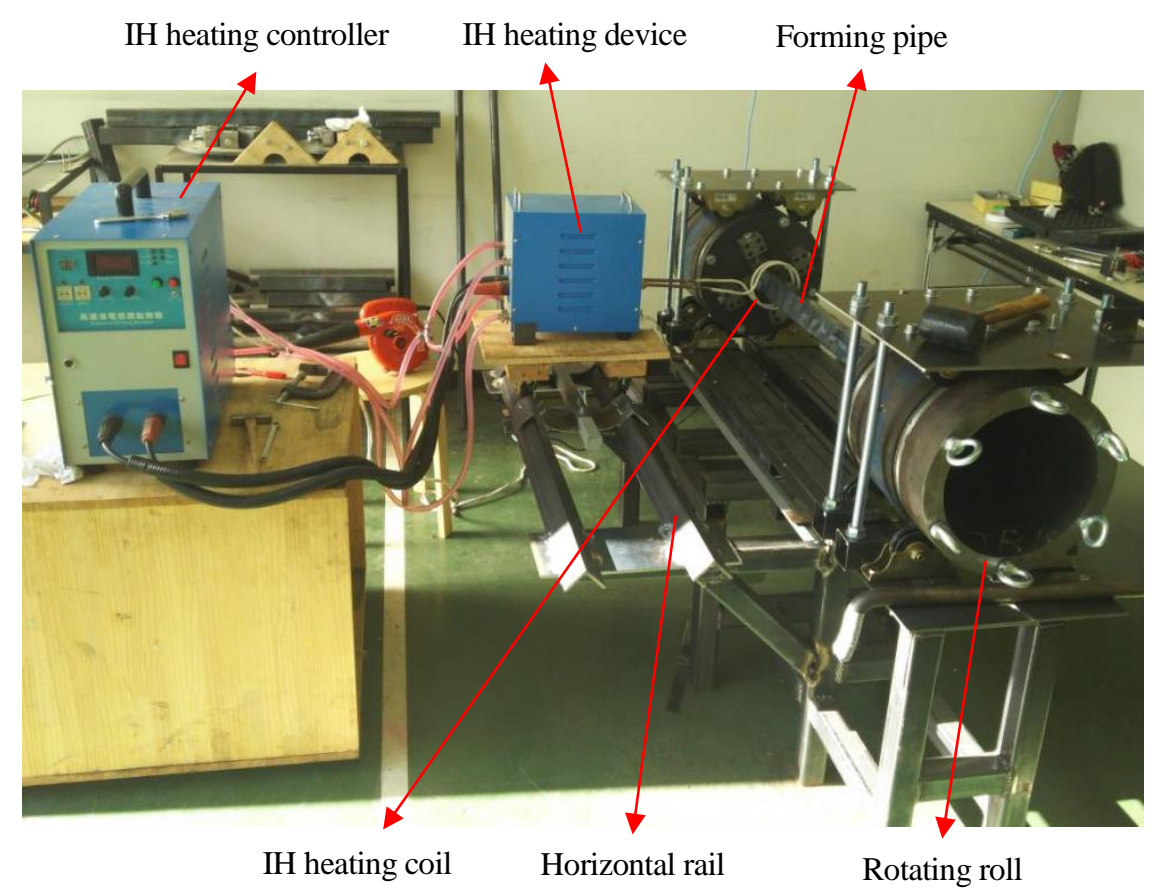

Fig.11 The RTO molding experimental equipment by partial heating torsion forming method. The experimental equipment is mainly composed of three parts, the processing equipment main frame, the square pipe fixing jig and the $\mathrm{IH}$ heater.

図 12 に示すのは，実際に RTO を部分加熱衩じり加工法で成形する様子である．具体的には，次の手順に従い RTO の成形作業を進めて行く.

（1）加熱コイルを通した成形用の角パイプを回転ロールの中央部にセットし，IH 加熱器を移動しながら成形 位置に合わせて調整する(図 12(a)) .

（2） IH 加熱コントローラーを使い加熱温度を成形過程において $950^{\circ} \mathrm{C}$ 前後に保つように設定する(図 12(b)).

（3）固定治具で成形用の角パイプを回転ロールの中央に固定する(図 12(c)).

（4）回転ロールの片側の端部を回転しないように実験装置のメインフレームに固定する(図 12(d)).

（5）加熱コイルを角パイプの成形部位の両側において, 成形品の最終形状に加工したいねじり角度に合わせ て，レーザー距離計と目盛板からなるインジケーターをセットしておく(図 $12(\mathrm{e}))$.

（6）レーザ温度測定器を使い，加熱部位の局部温度を計測する. 約 50 秒程度で $950^{\circ} \mathrm{C}$ 前後に温度上昇するこ とが確認される(図 12(f)) .

（7）バールを使い人力で回転ロールを回して，インジケーターに示されたねじり角度位置まで角パイプの部分 ねじり塑性成形を行う (図 $12(\mathrm{~g})$ ).

（8）角パイプの部分衩じり塑性成形が完了した後, ブロワーバキュームを使い敞じり成形した部位を冷却させ る(図 12(h)).

角パイプの軸方向に沿って, 各成形段部に対し順番に同様な部分加熱ねじり成形作業を行い, 最終的に RTO 構 造を得る. 


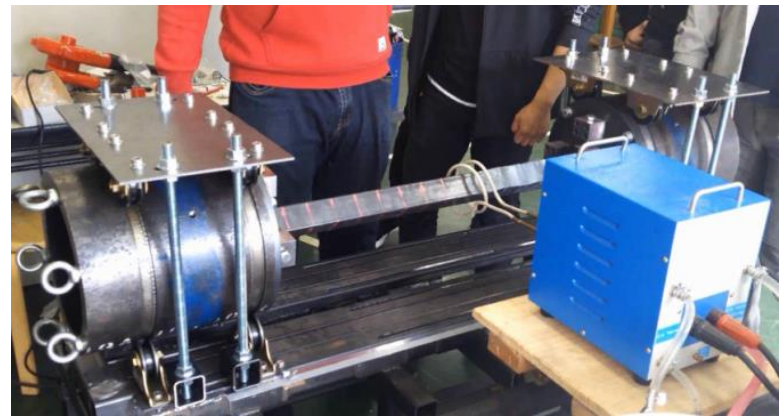

(a)

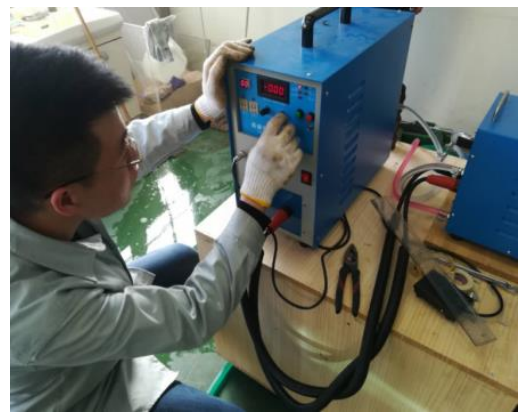

(b)

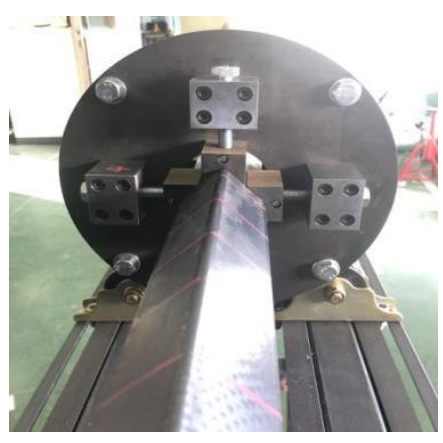

(c)

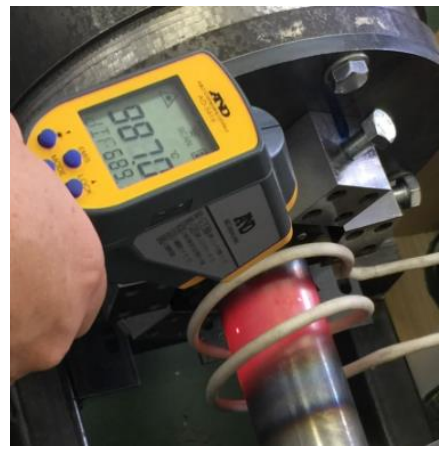

(f)

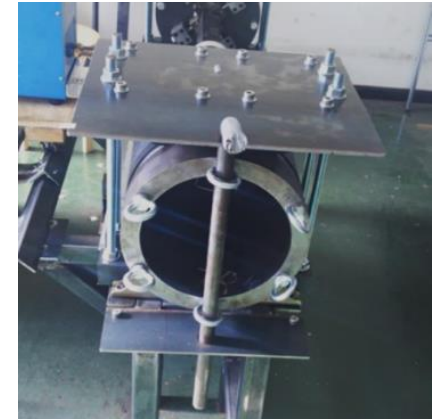

(d)

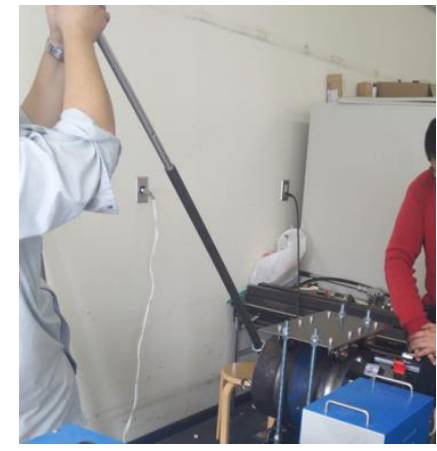

(g)

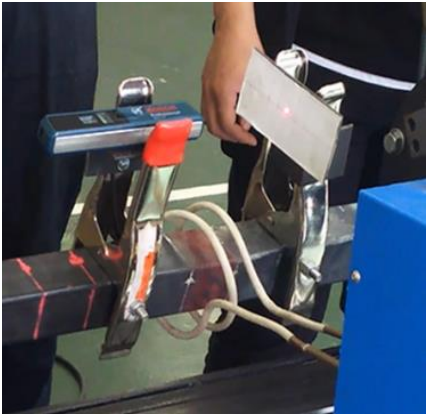

(e)

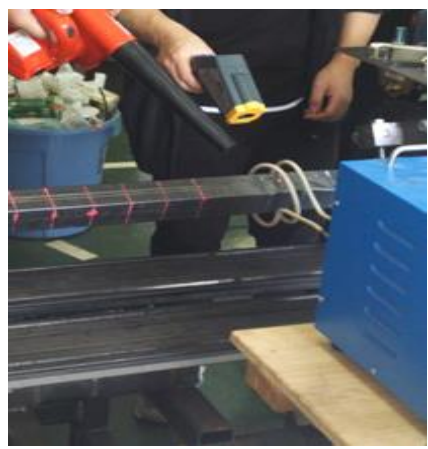

(h)

Fig.12 The forming flow of partial heating torsion forming method. (a) Set the forming pipe. (b) Set the heating strength by IH heating controller. (c) Fix the forming pipe on tools of rotating roll. (d) Fix the end of rotating roll on the main frame. (e) Adjust the torsion angle by the indicator. (f) Measure the local temperature of forming pipe. (g) Perform the twist forming of the pipe by the hand. (h) Cool the formed part of the pipe. Repeat these operations to obtain the final formed RTO.

ここで成形解析と部分加熱ねじり成形で得られる RTO 形状の比較結果を図 13 に示す. 同図 (a)に示すのは成 形解析で得られる形状, 同図 (b)に示すのは実際に試作実験で得られる形状の写真である. その 3 次元形状の代 表寸法として側面要素の対角線の長さを比較する．RTO の固定端に近いほど対角線の長さは僅かに短くなる傾 向が見られるものの，その差異の平均值は $1 \%$ 以内であることが判る.

成形した RTO の板厚変化を調べるため，図 14(a)に示すようにRTO の軸方向に沿って 1/4 部分を切り取り，同 図 (b)に示すラインに沿った代表点での板厚の, 市販の $0.01 \mathrm{~mm}$ 精度のダイヤルゲージでの計測值は全て $1.60 \mathrm{~mm}$ である. 同図 (c)に示す FEM 解析で得た代表点の板厚と比較して, その結果を図 15 に示す. 同図より，成形し た RTOの板厚変化はかなり小さく, 成形解析通りの成形が得られていると言える. 
(a)

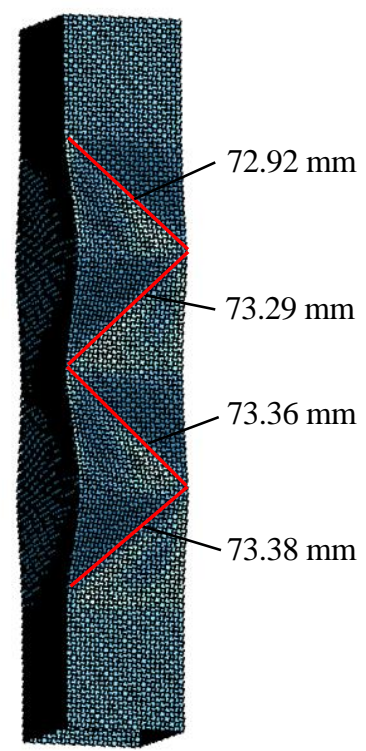

(b)

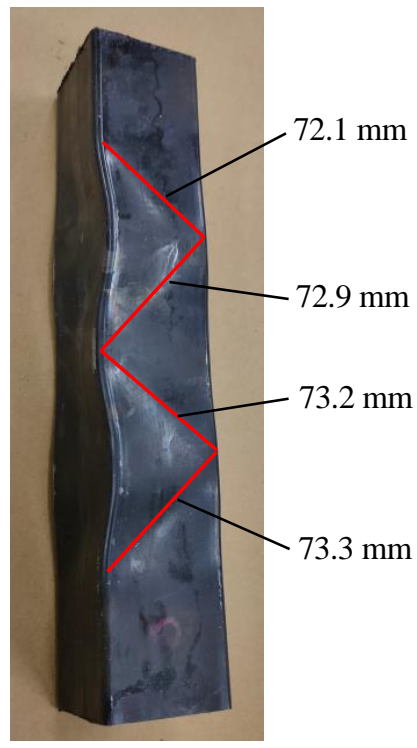

Fig.13 Verification result of shape processing accuracy by partial heating torsion forming method. (a) The shape obtained by forming analysis. (b) The shape obtained in trial forming experiment. The element length in the experiment tends to be slightly shorter than that in simulation, but the mean difference is within $1 \%$.

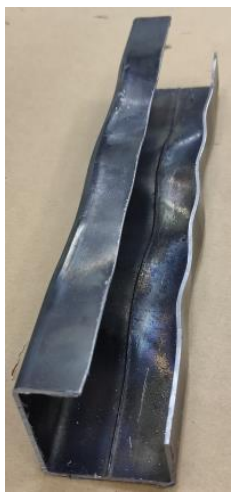

(a)

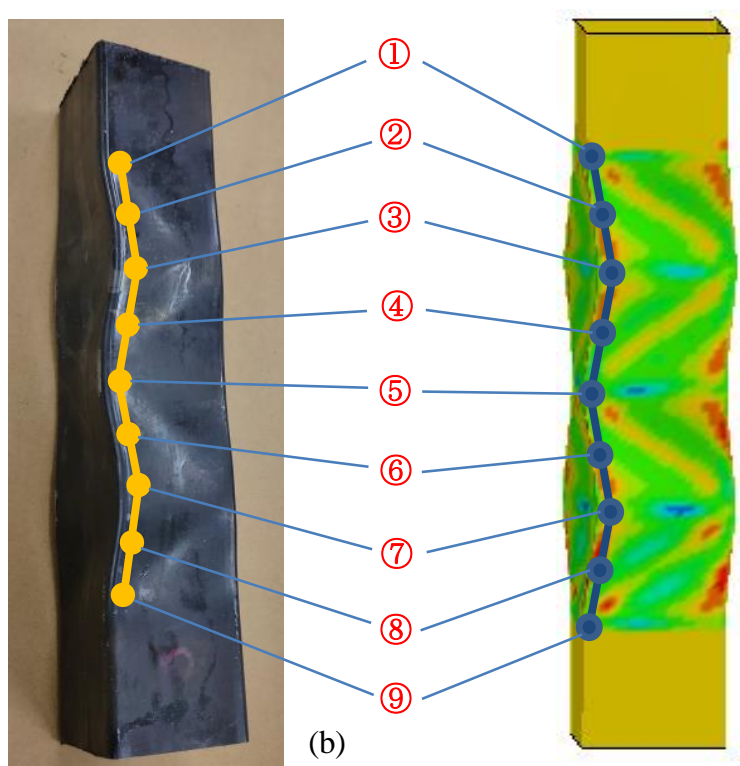

(c)

Fig.14 Observation points of RTO wall thickness distribution obtained by partial heating twisting method. (a) 1/4 cut along the axial direction of the RTO. (b) The list of observation points on the RTO obtained in trial forming experiment. (c) The list of observation points on the RTO obtained by forming analysis. The thickness at points along the line in (b), as measured using a dial gauge with accuracy of $0.01 \mathrm{~mm}$, is $1.60 \mathrm{~mm}$, which is the same thickness as before molding. It can be said the molding is the same as simulation.

\section{5. シミュレーションと計測実験による RTO の性能比較}

\section{$5 \cdot 1$ RTO の圧潰変形性能について}

RTO の圧潰変形性能を検証するため, 部分加熱ねじり成形法で得られた RTO に対してオートグラフ試験機に 


\section{よる圧潰試験と FEM 圧潰解析をそれぞれ行い，その結果を比較する.}

図 16(a)に示すのはオートグラフ試験機による圧潰試験の様子である. 圧潰試験に使用するオートグラフ試験機 は島津社製の AG-X/R300KNG であり，軸方向に圧縮荷重を与えるように，圧潰試験の前に，部分加熱ねじり成 形法で得られた RTO の両端の横断面を平らに機械加工しておく.オートグラフ試験機の圧縮治具を移動速度 $5 \mathrm{~mm} / \mathrm{s}$ に設定して強制変位の形で圧縮荷重を与える.

図 16(b)に示すのは FEM 圧潰変形解析モデルである．RTO の下端面に固定の境界条件を与え，上端面に圧潰試 験と同様に強制変位の形で圧縮荷重を与える.

図 17(a)に圧潰試験で得られた RTO 圧潰変形後の形状を示し，同図 b)に FEM 圧潰解析で得られた RTO 圧潰変 形の形状を示寸. 図中により双方の圧潰変形パターンは似ていることが判る.さらに比較するために, 図 18 に圧 潰試験と FEM 圧潰解析で得られた荷重変位線図を示寸.

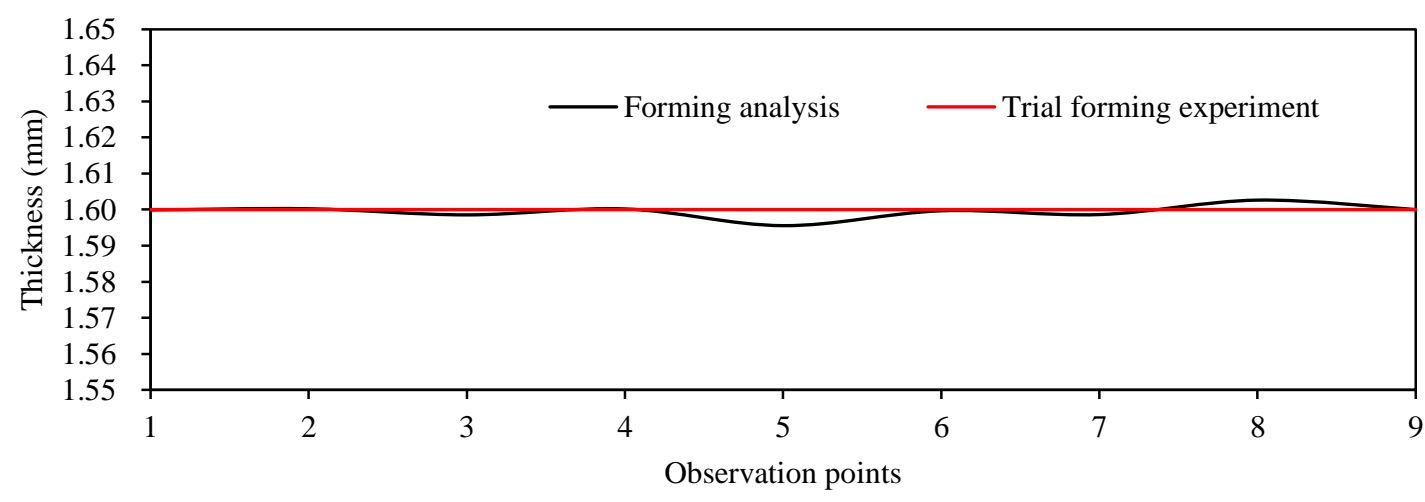

Fig.15 Verification result of RTO wall thickness distribution obtained by partial heating twisting method.

The change of RTO thickness is rather small. It can be said the molding is the same as simulation.

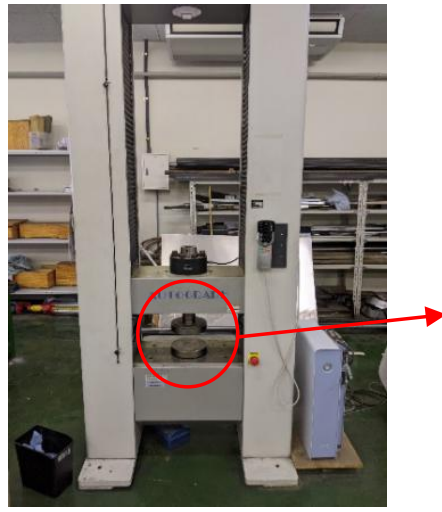

(a)

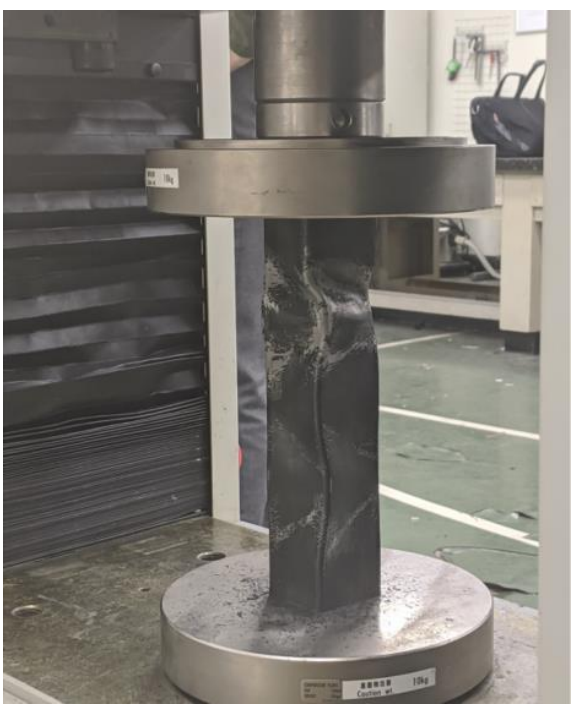

Forced displacement

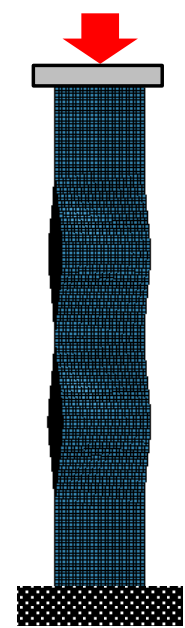

Fig.16 The crush test is performed using an AG-X/R300KNG autograph tester made by Shimadzu (a). A compressive load is loaded by forced displacement of the compression jig of the autograph tester at a speed of $5 \mathrm{~mm} / \mathrm{s}$. The FEM model (b), where a boundary condition is applied to the bottom surface and the crushing load is applied to the top surface through forced displacement as in the crush test. 
(a)

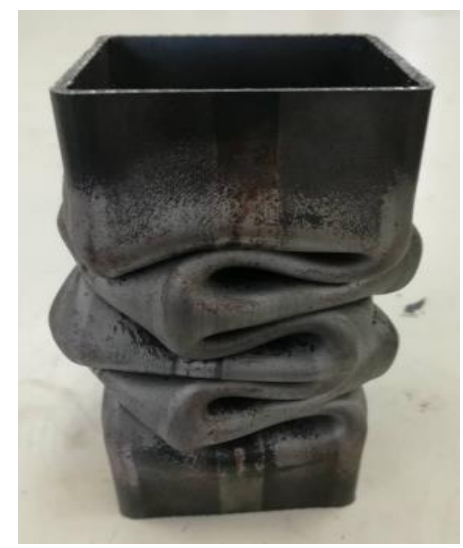

(b)

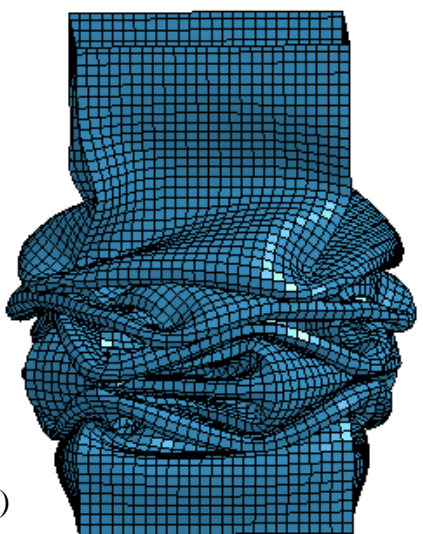

Fig.17 Results of crushing deformation of RTO. (a) The shape obtained by crushing test with autograph tester. (b) The shape obtained by crushing analysis by FEM. The crushing deformation patterns are similar to each other.

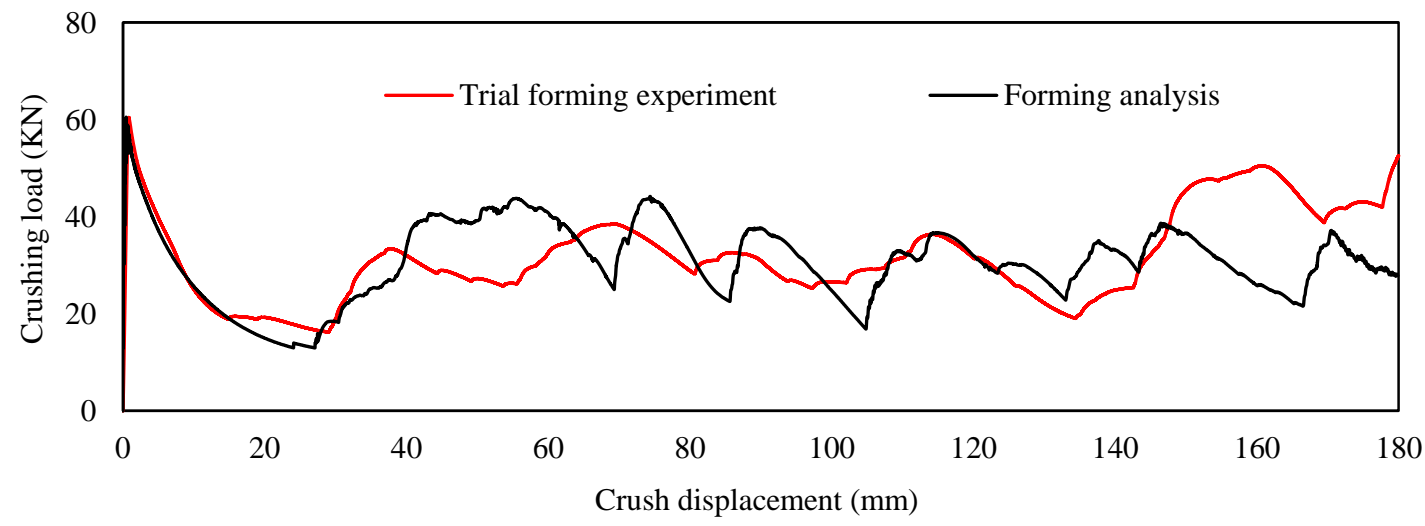

Fig.18 The measurement result of crushing deformation performance of RTO. The two crushing deformation patterns are similar in that the initial peak load is rather low and the load after the initial peak load does not fall greatly because the crushing mode continues without bending.

図 18 の圧潰変形荷重の結果により, 成形品のローカル的な材料不均一や圧潰荷重等による影響が考えられ, 部分的には差があるが，全体的な傾向を観察して見れば，両者とも，初期ピーク荷重值は比較的小さく，その後 の荷重值も大きく落ちることはなく，圧潰変形が長く続く特徵が見られる。すなわち図 1 に示すような高い初期 ピーク荷重はなく，圧潰変形途中で折れ曲がらずに潰れ量が長いなどと理想的な圧潰変形パターンであることを

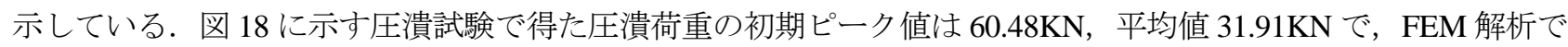
得た圧潰荷重の初期ピーク值は $60.53 \mathrm{KN}$, 平均值 $30.78 \mathrm{KN}$ である. よって, 両者の初期ピーク荷重值と平均值は かなり近いことで，得られた圧潰変形荷重が妥当であることが判る.

\section{5・2 RT0 の衝突エネルギ一吸収性能について}

RTO の衝突エネルギー吸収性能を確認するため, RTO と従来の研究で取り扱っている衝突エネルギー吸収構 造に対して，同じ解析条件の下でそれぞれ FEM 衝突解析を行い比較する.

比較解析の対象を RSO（趙他，2010）及び正方形断面の角筒として，出来るだけ同じ条件の下で比較解析を行 うため, 構造の長さは $375 \mathrm{~mm}$, 断面周長は $180 \mathrm{~mm}, \mathrm{RTO}$ と RSO の㧖じり角度を 5 度と同様に設定し，成形解 析で得られた板厚分布結果と材料特性をそれぞれの衝突解析モデルに反映させる.解析モデルの上端面に $1000 \mathrm{~kg}$ の集中質量をつけ衝突速度 $15 \mathrm{~m} / \mathrm{s}$ の同じ条件の下で衝突解析を行う。

衝突後の圧潰変形の様子を図 19 に示す.ただし, 正方形角筒の場合は, 横へ折り曲がる圧潰変形するパターン 


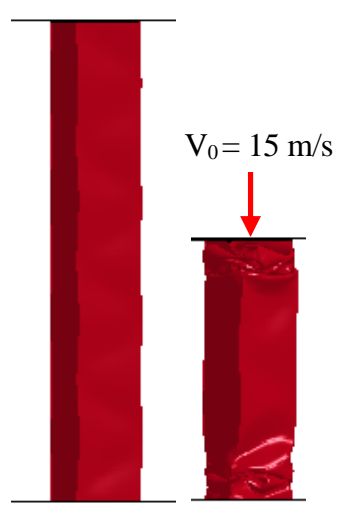

(a)

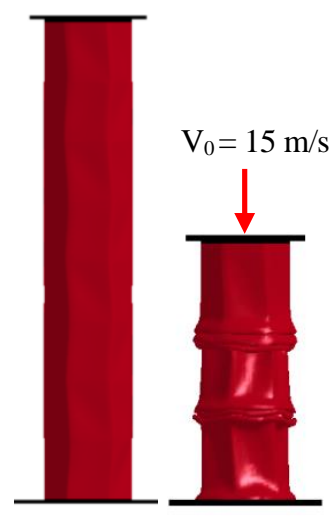

(b)

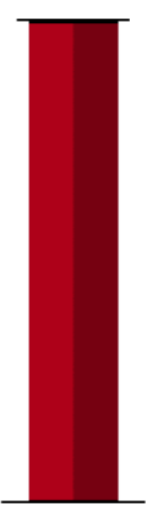

(c)

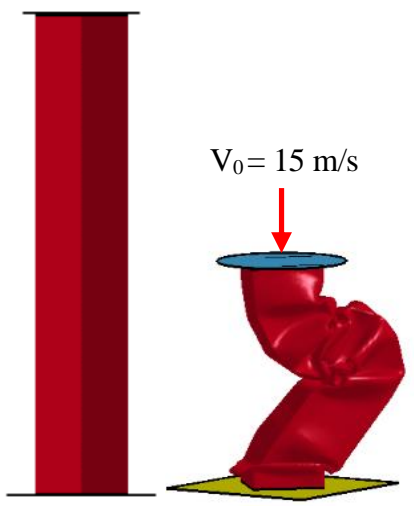

(d)

Fig.19 States of crushing deformation by comparative analysis of collision energy absorption performance. (a) RTO structure. (b) RSO structure. (c) The crushing deformation case the square tube does not collapse. (d) The crushing deformation case where the square tube collapses. RTO undergoes continual deformation with fine buckling wrinkles from the top surface. This is considered a main reason that the RTO has high energy absorption. Not only is the accuracy of shape molding sufficient but also there is high energy absorbance with the rounded edge after molding.

Table 2 Comparison of crush energy absorption between RTO and other thin cylinders by FEM (Unit: MJ) RTO has 1.1times as much energy absorption as RSO and 1.78 times as much energy absorption as a tube with a square cross section in continual axial crushing.

\begin{tabular}{|c|c|c|c|c|}
\hline \hline & RTO & RSO & Non collapse & Collapse \\
\hline Crash energy absorption & 8.92 & 8.11 & 5.02 & 4.47 \\
\hline
\end{tabular}

と最後まで圧潰変形が続くパターンの二つの結果が存在する. FEM 衝突解析で得られた衝突エネルギー吸収量 の比較結果を表 2 に示す. 図 19 により，衝突変形途中では，RTO の変形パターンは他の構造に比べて，端面か ら細かい座屈しわが順番に積み重ねながら変形が進む特徴が見える。これは表 2 に示すように RTOの衝突エネ ルギー吸収量が最も多い原因の一つになると思われる.

部分加熱礼じり加工法の形状加工精度は十分高いだけでなく，成形された RTO の稜線に沿って丸みが付けら れており，それによって RTO 構造の衝突エネルギー吸収性能の向上に寄与している.

\section{6. 結 言}

本報では，従来より衝突エネルギー吸収体の性能向上および加工困難の問題を解決するため，新たに安価な方 法で加工できる部分加熱ねじり加工法とそれによって得られる RTO を提案し，以下の結果が得られた.

（1）本報提案の RTO は部分加熱ねじり加工法を用い安価に加工することができ，従来のハイドロフォーミ ング加工法のような張り出し変形モードはなく, 単純ねじり塑性変形だけで成形するため, 得られる成形品の板 厚はほとんど元の板厚と変わらなく, 安定的に成形できることを示した. さらに, 軸方向に沿って段毎に成形し ていくため，必要な加工設備は安価に用意できるものであり，また軸方向長さの制限はないので，従来の塑性加 工法より，大型成形機械と金型が省略可能なことから，本報の提案する部分加熱ねじり成形法の優位性が明らか になった.

（2）シミュレーションの検討結果により，本報提案の RTO は，圧潰反力の初期ピーク值や荷重值のフラッ 卜性などの特性において理想的な圧潰変形パターンに近く, 従来の衝突エネルギー吸収体より多くエネルギーを 吸収することが確認できた。 
(3) RTO は側面に沿って折線配置により座屈しわの分布を調整することができ, 衝突時の圧潰変形過程にお いて安定的にアコーディオン型の圧潰変形を最後まで続く特性をもつことが確認できた. 本報の研究結果により, 3 次元的な形状をもつ折紙構造の加工困難な問題を解決することができ, 折紙構造を衝突エネルギー吸収体とし て実製品に組み込む目的に一歩前進したと考えられる．今後の研究課題としては，部分加熱礼じり加工法による 固定治具や回転装置などの自動化を実現させ，量産ベースの RTO の成形を実現し実機への応用展開を目指寸研 究開発を行う予定である.

\section{謝 辞}

本研究は，科研費基盤研究（c） NO.15K05769 と公益財団法人天田財団一般研究開発助成金 NO.AF-2017028 の援助を受けてなされた。ここに記して謝意を表す.

\section{文献}

Andrews, K.R.F., England, G.L. and Ghani, E., Classification of the axial collapse of cylindrical tubes under quasi-static loading, International journal of mechanical sciences, Vol. 25, No.9-10 (1983), pp.687-696.

萩原一郎, 津田政明, 北川裕一, ビードの配置決定方法, 特許第 2727680 号 (1991).

Hagiwara, I., Tsuda, M., Kitagawa, Y. and Futamata, T., method of determining positions of beads, United States Patent, Patent Number 5048345 (1991).

萩原一郎, 灘吉聡, 折り紙工学を利用した円筒構造物の圧潰解析, 自動車技術会論文集, Vol.34, No.4 (2003), pp.145-149.

萩原一郎, 山本千尋, 陶金, 野島武敏, 反転らせん型モデルを用いた円筒形折り紙構造の圧潰変形特性の最適化検 討，日本機械学会論文集 A 編, Vol.70, No.689 (2004), pp.36-42.

北川裕一, 萩原一郎, 津田政明, 有限要素法による薄肉任意断面形状部材の衝撃圧潰解析, 日本機械学会論文集 A 編, Vol.57, No.537 (1991), pp.1135-1139.

Kitagawa, Y., Hagiwara, I. and Tsuda, M., Development of a collapse mode control method for side members in vehicle collisions, SAE 910809 (1991), Transaction Section 6 (1992), pp.1101-1107.

孔呈海, 趙希禄, 萩原一郎, 円筒折紙構造のハイドロフォーミング工程の最適設計, 日本機械学会第 27 回計算力 学講演会論文集 (2014), pp.194-195.

Kong, C.H., Zhao, X.L. and Hagiwara, I., Hydroforming process of manufacturing for reverse spiral origami structure, International Journal of Vehicle Performance, Vol. 3, No. 4 (2017), pp.347-364.

楠見和久, 野村成彦, 真木純, ホットスタンプにおけるプレス成形性と成形解析技術, 新日鉄技報, No.393 (2012), pp.47-54.

Wu, Z., Hagiwara, I.and Tao, X., Optimization of crash characteristics of the cylindrical origami structure, International Journal of Vehicle Design, Vol.43, No.1-4 (2007), pp.66-81.

趙希禄, 胡亜波, 萩原一郎, 折紙工学を利用した円筒薄肉構造物の衝突圧潰特性の最適設計, 日本機械学会論文集 A 編, Vol.76, No.761 (2010), pp.10-17.

\section{References}

Andrews, K.R.F., England, G.L. and Ghani, E., Classification of the axial collapse of cylindrical tubes under quasi-static loading, International journal of mechanical sciences, Vol. 25, No.9-10(1983), pp.687-696.

Hagiwara, I., Tsuda, M. and Kitagawa, Y., Method of determining positions of beads, Patent Number 2727680 (1991) (in Japanese).

Hagiwara, I., Tsuda, M., Kitagawa, Y. and Futamata, T., Method of determining positions of beads, United States Patent, Patent Number 5048345(1991).

Hagiwara, I. and Nadayosi, S., Folding Process of cylindrical structures using origami model, International Journal of Automotive Engineering, Vol.34, No.4 (2003), pp.145-149 (in Japanese). 
Hagiwara, I., Yamamoto, C., Tao, X. and Nojima, T., Optimization for crash characteristics of cylindrical origami structure using reversed spiral model, Transactions of the Japan Society of Mechanical Engineers, Series A, Vol.70, No.689 (2004), pp.36-42 (in Japanese).

Kitagawa, Y., Hagiwara, I. and Tsuda, M., Dynamic analysis of thin-walled columns with arbitrary section geometry subjected to axial crashing, Transactions of the Japan Society of Mechanical Engineers, Series A, Vol.57, No.537 (1991), pp.11351139 (in Japanese).

Kitagawa, Y., Hagiwara, I. and Tsuda, M., Development of a collapse mode control method for side members in vehicle collisions, SAE 910809 (1991), Transaction Section 6 (1992), pp.1101-1107.

Kong, C.H., Zhao, X.L. and Hagiwara, I., Optimal design of hydroforming of the reversed-spiral-origami tube, JSME 27th Computational Mechanics Division Conference (2014), pp.194-195 (in Japanese).

Kong, C.H., Zhao, X.L. and Hagiwara, I., Hydroforming process of manufacturing for reverse spiral origami structure, International Journal of Vehicle Performance, Vol. 3, No. 4 (2017), pp.347-364.

Kusumi, K., Nomura, N. and Maki, J., Formability and FEM simulation of steel sheets in hot stamping process, Nippon Steel Technical Report, Vol.393 (2012), pp.47-54 (in Japanese).

Wu, Z., Hagiwara, I. and Tao, X., Optimization of crash characteristics of the cylindrical origami structure, International Journal of Vehicle Design, Vol.43, No.1-4 (2007), pp.66-81.

Zhao, X.L., Hu, Y.B., and Hagiwara, I., Optimization design of impact crashing characteristics for origami thin wall tube, Transactions of the Japan Society of Mechanical Engineers, Series A, Vol.76, No.761 (2010), pp.10-17 (in Japanese). 